\title{
Studies on milk productivity in primiparous Yaroslavl cows
}

\author{
T.A. Kadieva*, E.A. Valieva, Z.A. Karaeva, A.T. Kokoeva, A.T. \\ Kokoeva, F.T. Margieva
}

\author{
${ }^{1}$ Gorsky State Agrarian University, 362040, RNO-Alania, Vladikavkaz, Kirov Street, 37, Russian Federation; \\ *Corresponding author email: texmen2@mail.ru;
}

Journal of Livestock Scienc (ISSN online 2277-6214) 12: 198-201

Received on 6/5/21, Accepted on 15/6/21, Published on 8/7/21

doi.10.33259/JLivestSci.2021.198-201

\begin{abstract}
The lactation curve is determined by the level of milk productivity and individual characteristics of feeding and housing. The authors have researched the study of milk productivity of Yaroslavskaya breed cows and the influence of lactational activity in the conditions of Agricultural Production Cooperative ART of the PravoberezhnyDistrict of the Republic of North Ossetia - Alania in 2019-2020.The farm is located at $43^{\circ} 12^{\prime} 37$ "north latitude 4429'53" east longitude. When breeding "Yaroslavka", methods of selection and selection of animals were used without the use of foreign breeds, so that the Yaroslavl breed represents a separate population. Its allelofond differs significantly from that of other dairy breeds of cattle. Fifty-six first-calf cows were studied. When evaluating milk productivity, the following indicators were taken into account: milk yield for 90 and 305 days of lactation, fat and protein content, milk fat and protein, the highest daily milk yield, lactation fullness index, and lactation stability ratio. It was found that for the studied cows, the peak of lactation fell on the third month; the maximum milk yield was $434.8,566.9$, and $746.9 \mathrm{~kg}$, respectively, for the groups. The increase in milk yield for the first month was higher in the first group, with milk yields up to $3,000 \mathrm{~kg}-22.0 \%$, in the second and third groups $13 \%$ and $17.9 \%$, respectively. In the studied first-calf cows, the lactation constancy ratio was $91.1,82.6$, and $87.3 \%$, respectively, for the groups. The first-calf cows with the highest stable lactation curve had a higher lactation fullness ratio $-93.6 \%$. It should also be noted that cows with a lactation constancy ratio of more than $93.6 \%(2,109.0$ and $4,882.3 \mathrm{~kg}$ ) had high milk yields for the first 90 days and 305 days of lactation.
\end{abstract}

Keywords: Yaroslavl cows; milk production; mammary gland; milk yield; lactation; lactation activity; lactation curve. 


\section{Introduction}

Among the dairy breeds of cattle bred in the Russian Federation, a special place is occupied by the Yaroslavl breed, the "pearl" of national selection (Filinskaya et al, 2017).

Yaroslavl cattle are highly competitive in terms of economic and biological properties (disease resistance, reproductive function, productive longevity) and productive characteristics (milk yield, milk fat, and protein content) and surpass almost all the most common and predominant domestic and foreign breeds of dairy cattle in Russia (Muravyova et al, 2012).

In the Russian Federation, Yaroslavl cattle are bred in the Yaroslavl, Ivanovo, Tver, Kostroma, Moscow, Vologda, Kaluga, Bryansk Regions and the Stavropol Territory. As of 01.01.2019, there were 42,948 heads of controlled cattle of the Yaroslavl breed in the Russian Federation, including 26,493 cows. Currently, 10 genealogical lines are preserved in the breed.

Cattle dairy productivity indicators strongly depend on the specialization of breeds and are subject to large fluctuations under the influence of various reasons (Gogaev et al, 2015; Gogaev et al, 2016; Gogaev et al, 2017a; Gogaev et al, 2017b; Gogaev et al, 2018; Gogaev et al, 2019; Gojiev et al, 2018, López-González,et al, 2017).

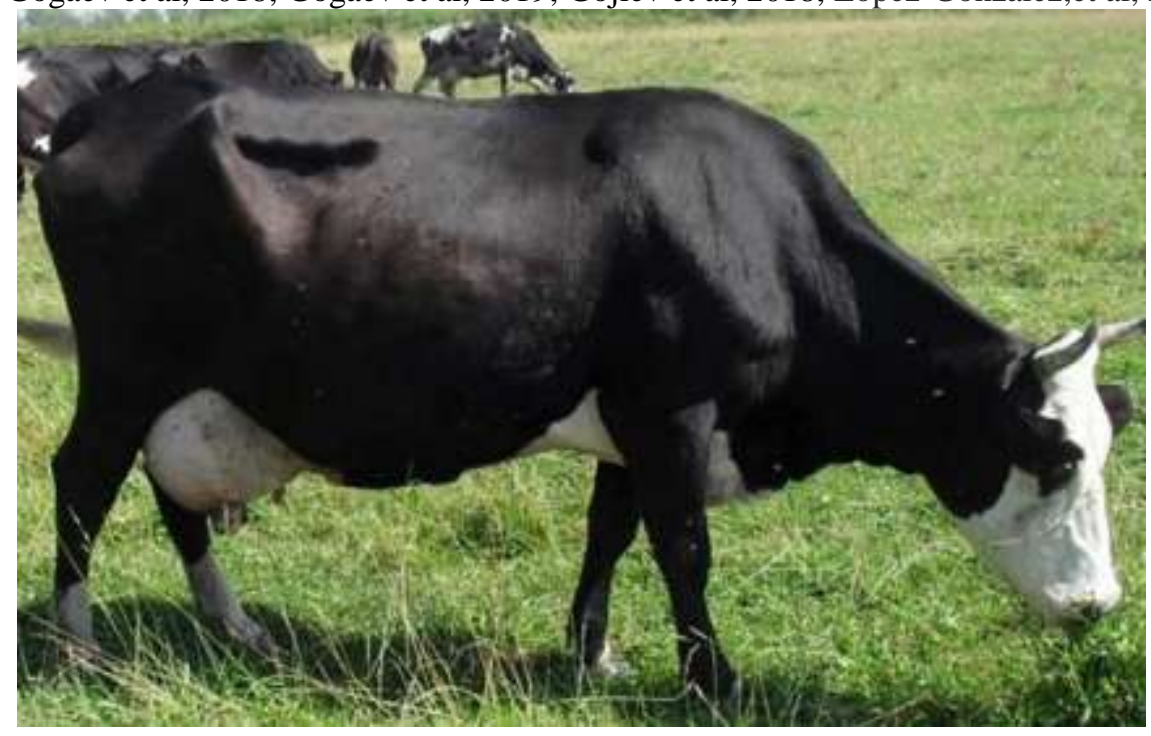

The increase in livestock productivity is directly related to the improvement of dairy characteristics. Milk yield is the essential breeding feature of cows. The importance of plentiful milk production of cows in modern conditions is not in doubt, since now milk is not only the most important food product: its production determines the economy of farms that raise dairy cattle (Sharma \& Singh, 2020). When evaluating cows and overall productivity, it is necessary to consider such valuable individual qualities as the ability to keep milk yields at a high level for a long time during lactation, the ratio of milk yields for different periods. The most valuable animals are those in which the leveled type of lactation and milk yield are kept reasonably constant for most of the lactation period. Among the factors that affect milk productivity, an important place is occupied by the uniformity of lactation activity, which is not used enough in breeding work.

The period from calving to drying is called lactation. The duration of lactation in animals of different breeds is different. In dairy cows, under the influence of milking, it is most prolonged. The longer the period from calving to fertilization, the longer is the lactation period. This applies mainly to cows with hereditary abilities for high productivity.

The milk yield for lactation is influenced by several physiological factors that contribute to the increase in milk productivity to a certain maximum, and then a gradual decrease and a drop by the end of lactation. Usually, the maximum daily milk yield is obtained at the end of the first and the beginning of the second month of lactation. Consequently, during lactation and at different times, an unequal amount of milk is formed in the cow's udder; its qualitative composition also changes.

The uniformity of lactation activity, which is not used enough in breeding work, is also among the factors affecting the level of milk productivity (Kadieva et al, 2011;Kadieva et al, 2018;Karaeva et al, 2017;Karaeva et al, 2018).

\section{Material and methods}

The authors have researched the study of milk productivity of Yaroslavskaya breed cows and the influence of lactational activity in the conditions of Agricultural Production Cooperative ART of the Pravoberezhny district of the Republic of North Ossetia - Alania in 2019-2020. The farm is located at $43^{\circ} 12^{\prime}$ ' 37 "north latitude $44^{\circ} 29^{\prime} 53^{\prime \prime}$ east longitude. The research was carried out based on the materials of primary, livestock, and breeding accounting of the farm.

The study was conducted on 56 first-calf cows. When evaluating milk productivity, the following indicators 
were taken into account: milk yield for 90 and 305 days of lactation, fat and protein content, milk fat and protein, the highest daily milk yield, LFI (lactation fullness index), and LSR (lactation stability ratio). The LFI was calculated using the formulas:

$$
\begin{gathered}
\mathrm{LFI}=\frac{\text { Milk yield per lactation, } \mathrm{kg}}{\text { Highest daily milk yield } \times \text { number of lactation days }} \times 100 \\
\mathrm{LSR}=\frac{\text { Milk yield in the second } 3 \text { months of lactation, } \mathrm{kg}}{\text { Milk yield in the first } 3 \text { months of lactation }} \times 100
\end{gathered}
$$

The entire population of first-calf cows was divided into three groups, depending on the level of productivity. The first group included animals with milk yield up to 3,000 kg, the second $-3,000-4,000 \mathrm{~kg}$, and the third - from 4,000 kg.

\section{Results}

The main advantage of the Yaroslavl breed is its high milk content. For lactation, a full-aged cow can give from 3,000 to 6,000 liters of milk. The fat content of milk is 4.5\%. During the scientific and economic experiment, the authors analyzed the productivity of cows of the Yaroslavl breed of the Agricultural Production Cooperative ART of the PravoberezhnyDistrict for three lactations. As a result of the analysis, it was found that the average milk productivity of the farm cows was $4512.4 \mathrm{~kg}$ for the first lactation with a fat content of $4.17 \%$.

It is known that milk productivity during lactation changes significantly; after calving, daily milk yields reach a maximum, usually at 2-3 months of lactation, then there is a gradual decrease. It should also be noted that milk yield depends on the degree of milk yield of the cow and the ability to maintain milk yield at a sufficiently high level for a long time.

The lactation activity of first-calf cows was studied by the change in milk yield during the entire lactation (by months of lactation). In addition, according to lactation curves constructed based on milk yield data,the authors also took into account the corresponding ratios (Figure 1). It was found that for the studied cows, the peak of lactation fell on the third month. The maximum yield was $434.8,566.9$, and $746.9 \mathrm{~kg}$, respectively, for the groups. The increase in milk yield for the first month was higher in the first group, with milk yields up to $3,000 \mathrm{~kg}-22.0 \%$, in the second and third groups $-13 \%$ and $17.9 \%$, respectively.

The stability of lactation characterizes the rate of reduction of milk yields after reaching the highest indicators. It is believed that the rate of falling milk yields during lactation depends on milk productivity in general. The cows of the Yaroslavl breed are characterized by smoothly falling lactation curves, which is typical for the animals studied in the Agricultural Production Cooperative ART; however, it should be noted that the cows of the third group are characterized by a more stable and smoothly falling lactation curve.

As a result of the research, the lactation fullness and constancy curve ratios were determined. The results are shown in Table 1. It was found that the Yaroslavl breed cows were characterized by a fairly high LSR, which in the studied first-calf cows was 91.1, 82.6, and 87.3\%, respectively. The first-calf cows with the highest stable lactation curve had a higher LFI - 93.6\%. It should also be noted that cows with anLSR of more than $93.6 \%$ $(2,109.0$ and $4,882.3 \mathrm{~kg})$ had high milk yields for the first 90 days and 305 days of lactation.

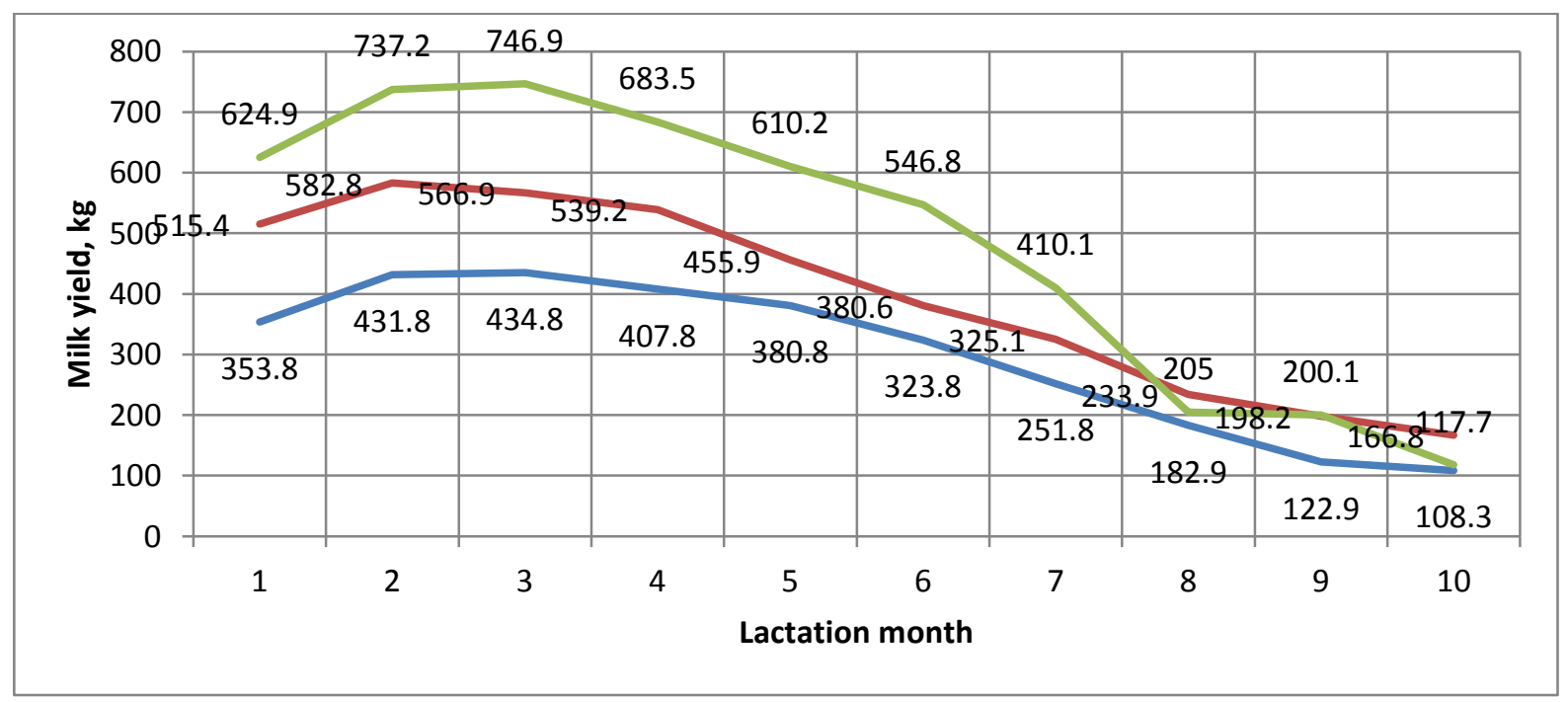

Figure 1. Lactation curves of first-calf cows

group 1

group 2

group3 
Table 1. Milk productivity of first-calf cows

\begin{tabular}{|l|c|c|c|}
\hline \multirow{2}{*}{ Indicator } & \multicolumn{3}{|c|}{ Productivity level } \\
\cline { 2 - 4 } & I (up to 3,000 kg) & II (3,000-4,000 kg) & III (> 4,000 kg) \\
\hline $\mathrm{n}$ & 6 & 18 & 32 \\
\hline $\begin{array}{l}\text { Milk yield for the first 90 days } \\
\text { of lactation, kg }\end{array}$ & $1,220.4 \pm 64.5$ & $1,665.1 \pm 76.8$ & $2,109.0 \pm 85.3$ \\
\hline $\begin{array}{l}\text { Milk yield for 305 days of } \\
\text { lactation, kg }\end{array}$ & $2,998.7 \pm 47.2$ & $3,964.8 \pm 54.6$ & $4,882.3 \pm 76.4$ \\
\hline Highest daily milk yield, kg & $15.4 \pm 1.9$ & $16.8 \pm 2.4$ & $17.1 \pm 2.1$ \\
\hline Lactation fullness index & $63.8 \pm 3.9$ & $77.3 \pm 2.7$ & $93.6 \pm 2.2$ \\
\hline Lactation constancy ratio & $91.1 \pm 1.1$ & $82.6 \pm 3.4$ & $87.3 \pm 2.8$ \\
\hline
\end{tabular}

Conclusions. Thus, for a reasonable genetic improvement of a herd of dairy cattle, it is important to evaluate cows in terms of milk productivity, taking into account the individual biological characteristics of the animals. Data on the productivity with different LCRs can become an additional test in selecting Yaroslavl cattle. Cows in the herd should be selected for the breeding core with a high LCR in the first lactation while respecting the feeding norms.

\section{References}

1) Filinskaya O.V., Ivachkina O.V. 2017. Characteristics of Indices of Lactation of Cows of Yaroslavl Breed. Agroindustrial Complex of Upper Volga Region Herald. 4: 12-17.

2) Gogaev, O.K.,Kadieva, T. A. 2017. Exterior and productive characteristics of the cows schwyz breed of different production types. Dairy and Beef Cattle Farming. 1:16-18.

3) Gogaev O.K., Kebekov M.E., Kadieva T.A., Tokhtieva E.A. 2017. Morphological and functional properties of cows' udder of holsteinized black pied breed. Dairy and Beef Cattle Farming. 4: 10-14.

4) Gogaev O.K., Kadieva T.A., Karapetyants A.N. 2015. Influence of fatness of cows on their dairy efficiency. Livestock of South Russia. 4(6): 29-32.

5) Gogaev O.K., Kadieva T.A., Demurova A.R., Gojiev R.S., Valieva E.A. 2019. Effect of certain factors on reproductive ability and dairy productivity of yaroslavl cows. Proceedings of Gorsky State Agrarian University. 56(3): 58-63.

6) Gogaev O.K., Ostaev G.Ya., Khosiev B.N. 2018. Product evaluations of beef cattle. Livestock of South Russia. 1(27): 31-33.

7) Gojiev R.S., Gogaev O.K., Tukfatulin G.S. 2018. Improving dairy cows productivity when using high-energy feed in their diets. Proceedings of Gorsky State Agrarian University. 55(3): 37-41.

8) Gogaev O.K., Kadieva T.A., Demurova A.R., Abdurakhimova A.N. 2016. Impact of service, dry and intercalving periods on the dairy productivity of black-motley breed cows. Scientific life. 2: 178-185.

9) Kadieva T.A., Soltanova I.Kh. 2011. Influence of duration and evenness of cows' lactations on their milk productivity. Proceedings of Gorsky State Agrarian University. 48(1): 94-96.

10) Karaeva Z.A. 2018. The influence of the differentiated diet structure on the milk quantity and quality by lactation periods. In Materials of the International Scientific and Practical Conference dedicated to the 100th Anniversary of the Gorsky State Agrarian University "Scientific support for sustainable development of the agro-industrial complex of mountain and foothill territories", pp. 181-186. Vladikavkaz.

11) Karaeva Z.A. 2017. The influence of the differentiated diet structure for lactation periods on the milk productivity and quality. In Materials of the All-Russian scientific and practical conference (correspondence) "Science achievements - agriculture", pp. 56-58. Vladikavkaz.

12) López-González F., Rosas-Dávila M., Celis-Alvarez M.D., Morales-Almaraz E., Domínguez-Vara I.A. and Arriaga-Jordán 2017. Milk production under grazing of different pasture grasses in small-scale dairy systems in the highlands of central Mexico. Journal of Livestock Science 8: 92-97

13) Muravyova N.A., Zvereva E.A. 2012. Possibility of combination of high dairy efficiency indicators by several signs at cows of the yaroslavl breed. Agro-industrial Complex of Upper Volga Region Herald. 3(19): 5154.

14) Sharma J.K. and Singh N.K. 2020. Economic studies on unorganized dairy farms in Jaipur region of Rajasthan. Journal of Livestock Science 11:127-132 